\title{
First record of the upper Illyrian ammonoid subzone marker Reitziites reitzi in the Karst Dinarides
}

The Mining-Geology-Petroleum Engineering Bulletin UDC: $551.7: 551.8$

DOI: 10.17794/rgn.2020.2.7

Original scientific paper

\author{
Duje Smirčić'; Dražen Japundžić; Nikolina GaberšeK', Dunja Aljinović́1, Nediljka Prlj-Šimić \\ Katarina Krizmanićz ${ }^{2}$ Uroš Barudžija ${ }^{1}$, Ivor Pavić ${ }^{1}$ \\ ${ }^{1}$ Faculty of Mining, Geology and Petroleum Engineering, University of Zagreb, Pierottijeva 6, HR10000 Zagreb \\ ${ }^{2}$ Croatian Natural History Museum, Demetrova 1, HR10000 Zagreb
}

\begin{abstract}
Middle Triassic deposits in the Karst Dinarides (south Lika area, near Gračac) were investigated for petrological, sedimentological and biostratigraphic determinations. Within two continuously recorded sections of sedimentary carbonates and interlayered pyroclastic rocks (Mali Kunovac and Kunovac sections) reflecting variable sedimentary-magmatic environments, valuable cephalopod fauna ranging from the middle Illyrian to the upper Illyrian age was found. The most significant was the recovery of the ammonoids Asseretoceras sp., indicating the upper part of the Illyrian Paraceratites trinodosus Zone, and Reitziites reitzi species which marks the upper part of the Illyrian Reitziites reitzi Zone. The discovery of the Reitziites reitzi species was not known from the Karst Dinarides until this finding.
\end{abstract}

Keywords:

Karst Dinarides, Croatia, Middle Triassic, biostratigraphy, ammonoids

\section{Introduction}

Biostratigraphic zonation according to ammonoids has a very high resolution and is still considered one of the best correlative principles for the Middle Triassic. There are many recent works that consider ammonoids as the important correlative marker in spite of the wide use of conodonts in biostratigraphic correlations. The Anisian-Ladinian boundary was defined by Brack et al. (2005) by means of ammonoids/conodonts. Our investigation was focused on ammonoid bearing Middle Triassic strata in the Karst Dinarides. The investigated area is located at the southern part of Lika, in Croatia. In the same area, the already known cephalopod bearing strata was recorded by Koch (1911) and Salopek (1914). Salopek (1914) collected a large number of cephalopod specimens and determined the existence of Ptychites Mojsisovics, Ceratites de Haan, Proarcestes Mojsisovics, Pinacoceras Mojsisovics and Gymnites Mojsisovics genera. According to the specimens collected from the green clastic rocks, Salopek (1914) determined the investigated area is of transitional Anisian-Ladinian age. Until today, no continuous sampling of ammonoids was conducted and this study therefore presents a new and precise biostratigraphic definition of the Middle Triassic. The two sections were investigated by means of petrography, sedimentology and ammonoid biostratigraphy.

Corresponding author: Uroš Barudžija

uros.barudzija@rgn.unizg.hr

\section{Geological setting}

The investigated area is located in the southern part of Lika, in Croatia. In a geological sense, the area represents the central part of the Karst Dinarides. The wider area of Kunovac has been investigated in the frame of basic geological mapping, and the area of our interest covers the parts of four sheets of the Basic Geological Map 1:100 000: Udbina (Šušnjar et al., 1973), Drvar (Šušnjar et al., 1978), Obrovac (Ivanović et al., 1973) and Knin (Grimani et al., 1972). All four sheets overlap in the wider area of Kunovac Creek (see Figure 1). According to the Geology of Knin sheet (Grimani et al., 1975), the investigated area is composed of two chronostratigraphic units $\left(\mathrm{T}_{2}{ }^{1}-\right.$ Anisian and $\mathrm{T}_{2}{ }^{2}$ - Ladinian, comprising various lithologies: (1) Anisian crystalline and white-brown limestones and grey-white poorly layered dolomites $\left(\mathrm{T}_{2}{ }^{1}\right)$, up to $550 \mathrm{~m}$ thick; and (2) Ladinian white-grey to white crystalline limestones and coarse-crystalline dolomites interlayered with volcanogenic sediments $\left(\mathrm{T}_{2}^{2}\right)$, up to $750 \mathrm{~m}$ thick. Towards the north, Lower Triassic units appear: $\mathrm{T}_{1}^{2}$ - clayey and sandy limestones, marls and dolomites (,Campiler beds" ${ }^{6}$ ), up to $470 \mathrm{~m}$ thick; and $\mathrm{T}_{1}{ }^{1}-$ micaceous and silty sandstones, various types of clayey and sandy limestones and marls (,Seisser beds"), up to $500 \mathrm{~m}$ thick. Towards the south, Upper Triassic dolomites, as well Lower Jurassic limestones and dolomites, follow. The investigated sections are located at the structural unit comprising of conformable succession, ranging from the early Triassic to the late Jurassic. The strata are 


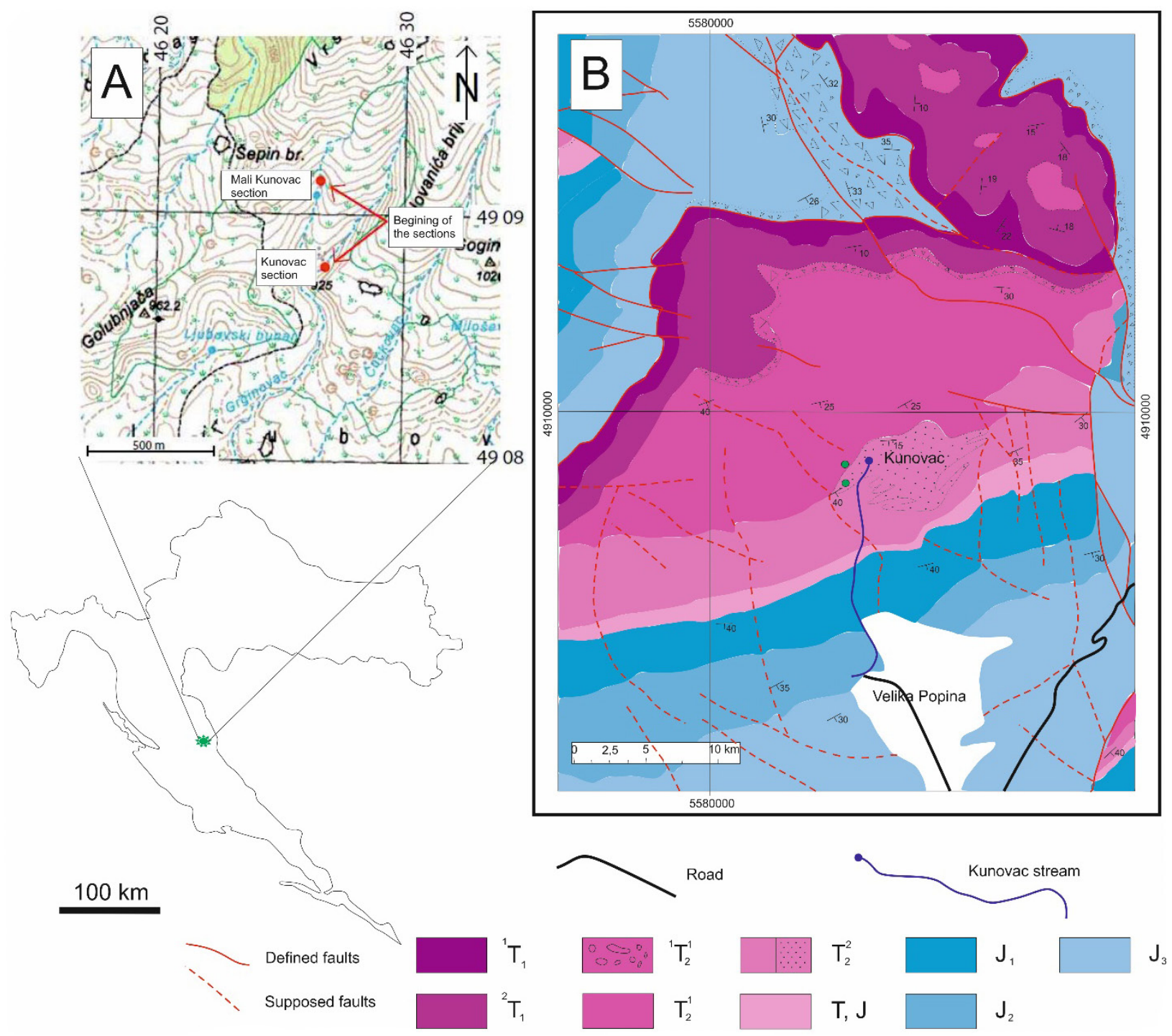

Figure 1. A map of the investigated area. An outline of the Republic of Croatia is presented in the lower part of the figure, with a green complex star marking the investigated area. A) A topographic map of the investigated area, with red circles marking the beginnings of the recorded sections. B) A geological map of the investigated area, combined from contiguous/marginal parts of the sheets of the Basic Geological Maps of SFRY 1:10o ooo: Udbina (Šušnjar et al., 1973), Drvar (Šušnjar et al., 1978), Obrovac (Ivanović et al., 1973) and Knin (Grimani et al., 1972). Green circles mark the investigated area and the localities of the recorded sections.

dipping to the south-southeast. In the north and northwest, the structural unit is bordered by a fault, bringing the early Triassic strata in contact with the late Jurassic deposits. The two recorded sections, named Mali Kunovac and Kunovac, were recorded in creek gullies and they can be correlated into one continuous section, with a covered interval in between. The older section is represented by the deposits of Mali Kunovac with its beginning marked on Figure 1.

\section{Methods}

Two sedimentary sections, named Mali Kunovac and Kunovac, were measured and sampled during detailed field work. Samples of different rock types were collected for micropetrographic and facies analysis. The thin sections were prepared at the Department of Mineralogy, Petrology and Mineral Resources of the Faculty of Mining, Geology and Petroleum Engineering, University of Zagreb, by the standard procedure, and stained with Alizarine red-S and K-ferricyanide to distinguish calcite and dolomite minerals. Twenty-two thin sections were prepared and analysed using a Leica DM/LSP polarizing microscope to determine micropetrographic features of the sampled rock types. Samples of different cephalopods were collected for biostratigraphic and paleoecologic investigations. Samples were prepared and determined at the Paleontological Department of the Croatian Natural History Museum. The genus and species of different cephalopods were determined according to the specific whorl morphological characteristics, including ornamentation and lobe line type. 


\section{Results}

\subsection{Investigated sections: Mali Kunovac and Kunovac}

The two sections, Mali Kunovac and Kunovac, represent a conformable Anisian/Ladinian transitional sedimentary succession (see Figures 1 and 2). The two sections are divided by an approximately 10 meter thick covered interval. Since no tectonic breaks are recorded and the layer orientation of both sections is the same (the general dip is towards the southeast, with inclinations of $\sim 25^{\circ}$ ), they are considered as a continuous depositional sequence, with the Mali Kunovac section representing the older, and the Kunovac section representing the younger strata (see Figure 2).

At the very base of the Mali Kunovac section, massive grey limestones occur (see Figure 2). Layers range from 1 to 2 meters in thickness (see Figure 3A). They are determined as bioclastic floatstone to grainstone. Fossil content is dominated by bivalves, brachiopods, crinoids, foraminifera, corals, echinoids, green algae, gastropods and bryozoans (see Figure 3B and 3C). Sometimes, even microbial (possibly cyanobacterial) fabric can be distinguished. A subordinate amount of various sized intraclasts are recognized. Lime mud-rich varieties show wackestone/floatstone fabric whereas sparite-rich varieties are dominated by grainstone fabric and sparry calcite cement.

The massive limestones are conformably overlain by a 2.5-meter-thick red nodular limestone bed (see Figure 3D). The interval is intensively silicified and contains pyroclastic detritus. A micropetrographical analysis revealed that the lowermost part of this interval consists of bioclastic grainstone with up to $30 \%$ of pyroclasts. The limestone component is presented by recrystallized intraclasts, bivalve fragments, crinoids and radiolarians. Pyroclastic material dominantly consists of hyaline lithic fragments, and subordinately of feldspar and quartz crystaloclasts. In the upper part of the red limestone interval, biomicritic limestone with dominantly pelagic fauna (thin-shelled bivalves, radiolarians and crinoid fragments), is recognized.

Red limestone is overlain by a meter-thick interval, consisting of the interlayered limestone and pyroclastic beds. Sometimes, horizontal lamination can be observed. Limestones from this interval are determined as biomicritic and lithoclastic limestones containing various amount of pyroclastic material. Biomicritic interlayers/ laminae contain radiolarians, thin-shelled bivalvs and crinoids, supported by lime mud (see Figure 4B). Lithoclastic limestones contain irregularly shaped limestone lithoclasts. Lithoclasts are dominantly of micritic and biomicritic types. Between the lithoclasts, sparry calcite cement was precipitated (see Figure 4A). Sometimes, a thin lamination with pyroclastic material occurs between the limestone laminae. Limestones are silicified and re- crystallized to a various extent. Pyroclastic material in the limestones are feldspar and quartz crystaloclasts, as well as hyaline lithoclasts. The majority of the ammonoid specimens were collected in this interval.

The top of the Mali Kunovac section is marked by a 4.5-meter-thick pyroclastic interval. The pyroclastic interval consists of greenish tuff layers (locally called the pietra verde) composed of fine ash material, and brown layers containing material of coarse ash size (see Figure 4C). Fine ash tuff layers have homogenous textures, and they are composed of very fine ash size glass shards (see Figure 4D). Exceptionally rare feldspar crystaloclasts were recognized. Coarse ash tuff, determined as crystalolithoclastic tuff, consists of plagioclase and quartz crystaloclasts, and subordinately of pumice fragments and lithoclasts. Most of the plagioclase crystaloclasts are altered to calcite and prehnite to a various extent. Irregularly shaped quartz crystaloclasts often exhibit oval cav-

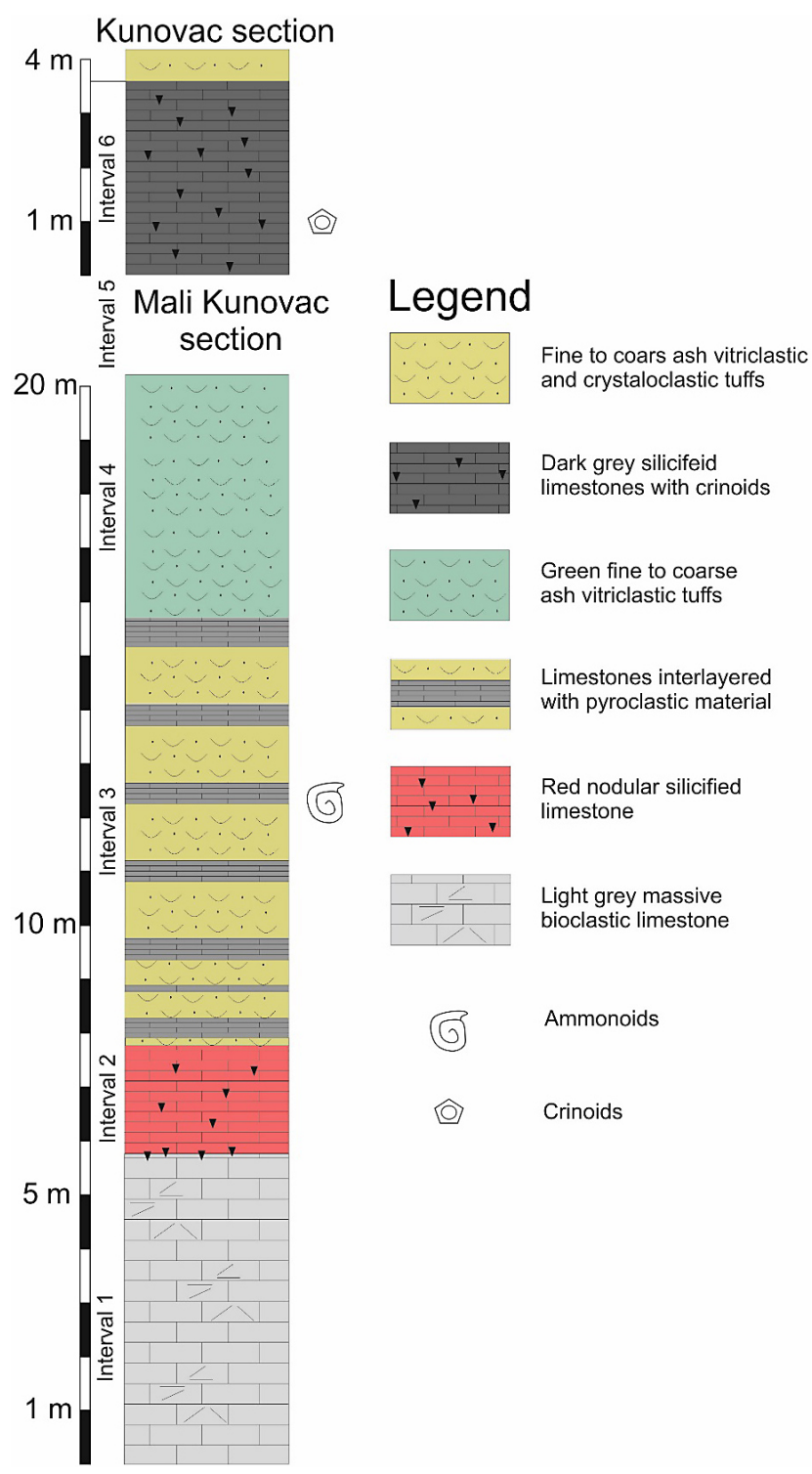

Figure 2. Recorded sections in the investigated area with varied lithology and determined macrofossils. 

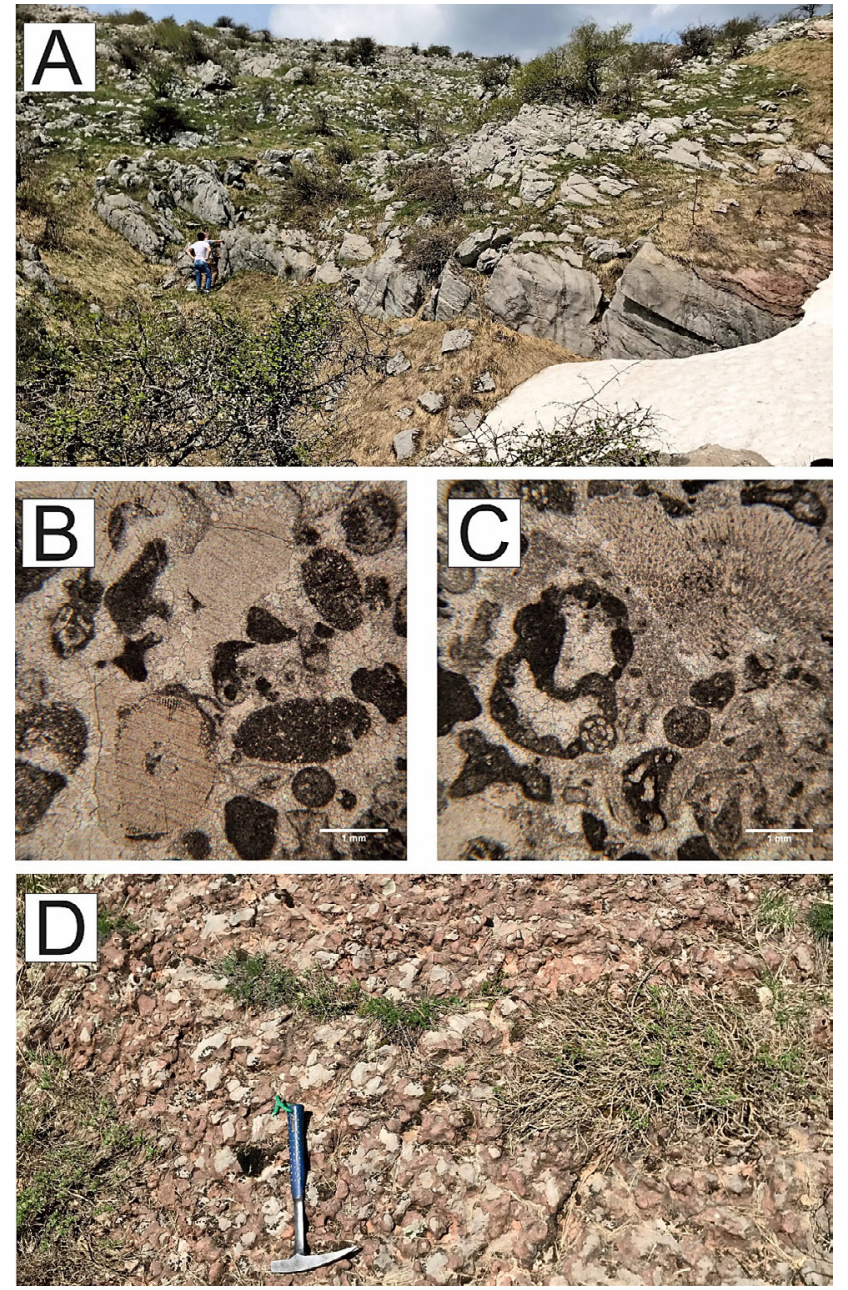

Figure 3. Field photographs and photomicrographs of the lithologies recognized in the Mali Kunovac section.

A) A field photograph of the massive grey limestones at the beginning of the Mali Kunovac section.

B) and C) Photomicrographs of grainstone/floatstone limestone types containing dominantly shallow marine fossils of foraminifera, green algae, corals and echinoids.

D) A field photograph of the red limestone layer with a nodular texture.

ities. Lithoclasts are dominantly of andesitic composition. Surprisingly, crinoid fragments are sometimes present. Between the pyroclasts, a matrix composed of very fine greenish hyaline material, can be observed.

The covered interval between the two recorded sections is probably composed of severely altered fine ash tuffs covered with vegetation. Fragments of fine greenish tuffs were found all along the covered interval.

The oldest rocks of the $3.6 \mathrm{~m}$ thick Kunovac section are platy limestones, rich in crinoid fragments (see Figure 2). Beds are up to $0.5 \mathrm{~m}$ thick, with an irregular or nodular silicification pattern observed within the layers. The silicified parts are yellowish to brownish in colour. The limestones in the Kunovac section are determined as lithoclastic limestone in the lower part, and packstone with pelagic fossils in the upper part of the interval.
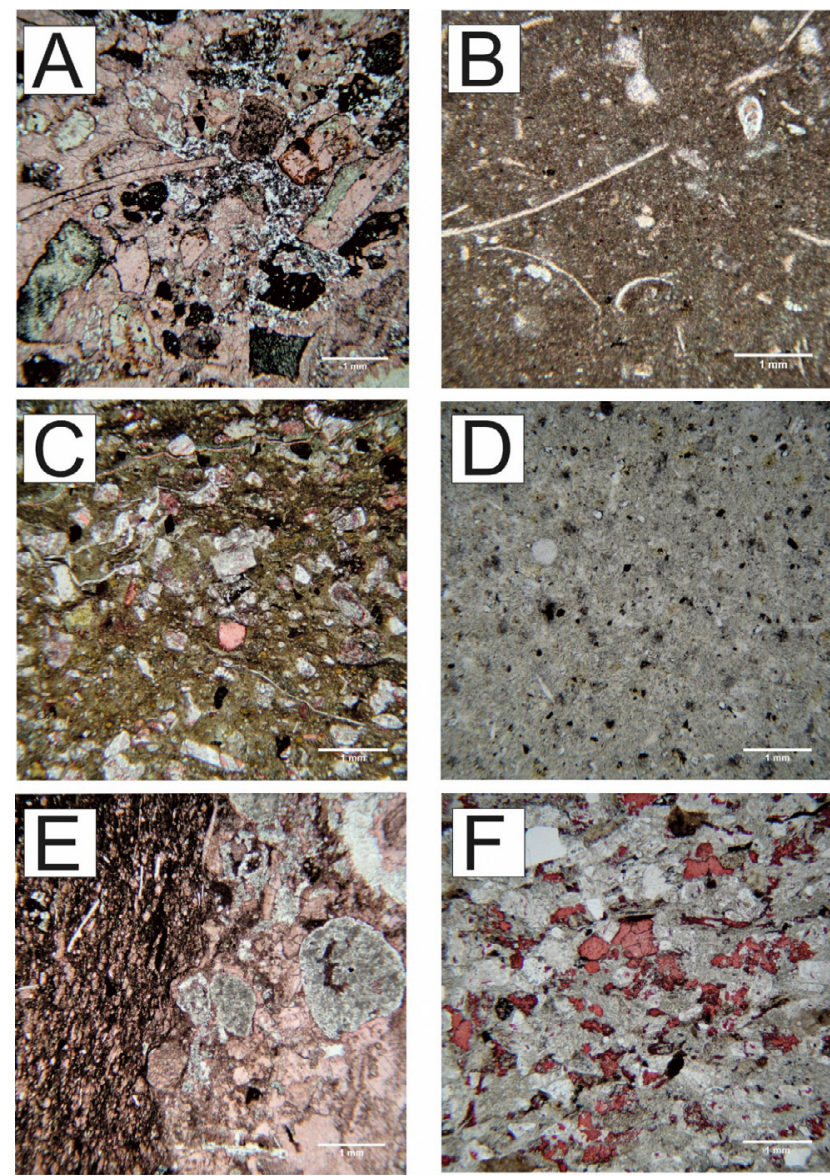

Figure 4. Photomicrographs of the samples from the Mali Kunovac section (A, B, C and D) and the Kunovac section (E and F). A) Lithoclastic limestone from the Mali Kunovac section containing lithoclasts of shallow marine biomicrite and different pyroclastic particles (white). B) Biomicritic

limestone - wackestone/packstone with pelagic fauna (radiolarians, thin-shelled bivalves). C) A sample of the pyroclastic layer found in the Mali Kunovac section. Note the greenish matrix composed of fine hyaline fragments.

D) Fine ash tuff composed of very fine glass shards - Mali Kunovac section. E) Recrystallized limestone (right) in contact with pyroclastic material (left) from the Kunovac section. F) Crystaloclastic tuff from the Kunovac section containing feldspar and quartz crystaloclasts.

Lithoclastic limestone, found in the lower part of the Kunovac section, contain extremely unsorted lithoclasts of various shallow water limestones with preserved marine fauna (echinoids, green algae, foraminifera, bivalves). Lithoclastic limestone beds are intensively silicified and recrystallized (see Figure 4E). Lithoclastic limestone is overlain by autochthonous limestones containing pelagic fossils and pyroclastic material. Limestones found in the upper part of the interval are determined as biomicrite, with a pronounced nodular silicification pattern. Fossils of thin-shelled bivalves, radiolarians, sponge spicules and crinoids were noticed. Pyroclastic material consists of plagioclase and irregularly shaped quartz crystaloclasts. Quartz crystaloclasts are usually finer than plagioclase. Sometimes, faint ir- 
regular lamination can be observed due to a change of pyroclastic components in each lamina.

Above the recorded Kunovac section, another horizon of pyroclastics was found and determined as fine ash vitriclastic tuff and coarse ash crystaloclastic tuff. Vitriclastic tuff is green, with a homogenous texture. They are composed of very fine needle-shaped glass shards and exceptionally rare plagioclase crystaloclasts. Crystaloclastic tuffs are dominantly composed of well sorted euhedral/subhedral plagioclase crystals, and subordinately quartz crystaloclasts (see Figure 4F). Quartz crystaloclasts are mostly irregular, rounded, and usually exhibit oval cavities. Scarce pumice fragments and andesite lithoclasts can also be recognized. A certain amount of crinoid fragments is present as well.

\subsection{Biostratigraphy}

During fieldwork, several samples of cephalopod fauna were collected. Ammonoid specimens were mainly concentrated in the interval of the limestones interlayered with pyroclastics from the Mali Kunovac section, and just below the green vitriclastic tuffs of the pietra verde type. In the Mali Kunovac section, from the unit of the limestones with pyroclastics (see Figure 2) a significant number of Ptychites specimens were collected, as well as several specimens of the genus Proarcestes Mo- jsisovics and Epigymnites ecki. The most significant findings in this interval are the specimens determined as the Reitziites reitzi ammonoid species. Based on the occurrence of the Reitziites reitzi, the stratigraphic position of the investigated strata is determined as the upper Illyrian Reitziites Zone (Brack and Rieber, 1993; Mietto et al., 2003; Balini et al. 2010). In the green vitriclastic tuffs, specimens of Asseretoceras sp. were discovered. According to the discovery of Asseretoceras sp., deposits in the investigated section are attributed to the upper part of the Paraceratites trinodosus Zone and the Reitziites reitzi Subzone (the upper part of the Reitziites reitzi Zone) (see Figure 5). The discovered cephalopod fauna is presented in Figures 6 and 7.

\section{Sedimentary model}

Massive grey limestones (at the base of the Mali $\mathrm{Ku}$ novac section - interval 1 in Figure 2) with the abundance of green algae, bivalves, brachiopods, corals, echinoids, gastropods and bryozoans in the beginning of the section indicate deposition in a shallow marine environment, probably in the shallow subtidal zone, since green algae are the dominant constituents. Reef organisms, such as corals and bryozoans, preserved as fragments, suggest redeposition of the fragmented debris

\begin{tabular}{|c|c|c|c|c|c|}
\hline \multirow{2}{*}{ Stage } & \multirow{2}{*}{ Substage } & \multicolumn{2}{|c|}{ Balaton Highland } & \multicolumn{2}{|c|}{ Eastern Lombardy } \\
\hline & & Zone & Subzone & Zone & Subzone \\
\hline Ladinian & Fassanian & $\begin{array}{c}\text { Eoprotrachyceras } \\
\text { curionii }\end{array}$ & $\begin{array}{c}\text { Eoprotrachyceras } \\
\text { curionii }\end{array}$ & $\begin{array}{c}\text { Eoprotrachyceras } \\
\text { curionii }\end{array}$ & $\begin{array}{c}\text { Eoprotrachyceras } \\
\text { curionii }\end{array}$ \\
\hline \multirow{16}{*}{ Anisian } & \multirow{12}{*}{ Illyrian } & \multirow{2}{*}{$\begin{array}{l}\text { Nevadites } \\
\text { secedensis }\end{array}$} & Nevadites secedensis & \multirow{2}{*}{$\begin{array}{l}\text { Nevadites } \\
\text { secedensis }\end{array}$} & Nevadites secedensis \\
\hline & & & Ticinites crassus & & Ticinites crassus \\
\hline & & \multirow{4}{*}{ Reitziites reitzi } & Aplococeras avisianum & \multirow{4}{*}{ Reitziites reitzi } & Aplococeras avisianum \\
\hline & & & Reitziites reitzi & & Reitziites reitzi \\
\hline & & & Hyparpadites lieopoldti & & Hyparpadites bagolinensis \\
\hline & & & Kellnerites felsoeoersensis & & "Kellnerites" \\
\hline & & \multirow{6}{*}{$\begin{array}{l}\text { Paraceratites } \\
\text { trinodosus }\end{array}$} & $\begin{array}{c}\text { Lardaroceras } \\
\text { pseudohungaricum }\end{array}$ & \multirow{6}{*}{$\begin{array}{l}\text { Paraceratites } \\
\text { trinodosus }\end{array}$} & "Lardaroceras" \\
\hline & & & Asseretoceras camunum & & "Asseretoceras" \\
\hline & & & \multirow{2}{*}{ Paraceratites trinodosus } & & Paraceratites trinodosus \\
\hline & & & & & Schreyerites abichi \\
\hline & & & \multirow{2}{*}{ Schreyerites ? binodosus } & & Judicarites eurycenphalus \\
\hline & & & & & Rieberites transiformis \\
\hline & \multirow{3}{*}{ Pelsonian } & \multirow{3}{*}{$\begin{array}{l}\text { Balatonites } \\
\text { balatonicus }\end{array}$} & Bulogites zoldianus & \multirow{3}{*}{$\begin{array}{l}\text { Balatonites } \\
\text { balatonicus }\end{array}$} & \multirow{2}{*}{ Bulogites zoldianus } \\
\hline & & & Beyrichites cadoricus & & \\
\hline & & & Balatonites balatonicus & & Balatonites balatonicus \\
\hline & Bithynian & $\begin{array}{l}\text { Aghdarbandites } \\
\text { ismidicus }\end{array}$ & Balatonites ottonis & $\begin{array}{l}\text { Aghdarbandites } \\
\text { ismidicus }\end{array}$ & Balatonites ottonis \\
\hline
\end{tabular}

Figure 5. Biostratigraphic subdivision of the Middle Triassic, after Vörös (2014). Zones marked in blue represent the biostratigraphic position of the fauna recovered in this investigation. 




Figure 6. 1. Ptychites oppeli MOJSISOVICS, 1882 - INV 1001, Kunovac 1., Reitzi Zone (?), a: lateral view, b: ventral view, 2. Ptychites oppeli MOJSISOVICS, 1882- INV 1025, Kunovac, Reitzi Zone (?), lateral view, 3. Ptychites sp.- INV 1022, Kunovac 1., Reitzi Zone (?), a: lateral view, b: ventral view, 4. Epigymnites ecki (MOJSISOVICS, 1882) - INV 569, Kunovac l., Reitzi Zone (?), a: lateral view, b: ventral view, 5. Trematoceras cf. campanile (MOJSISOVICS, 1882) — INV 1034, Kunovac l., Reitzi Zone (?), a: lateral view, 6. Proarcestes sp. — INV 1016, Kunovac 1., Reitzi Zone (?), a: lateral view, b: cross-section.

from the nearby existing reef areas. Fragmentation was possibly caused by severe waves that also caused the resedimentation of the material. The deposition of carbonates in the shallow marine area was interrupted by episodes of explosive volcanism, indicated by the presence of limestones interlayered with pyroclastic deposits, just on top of the massive grey limestones (see Figure 2). The influence of volcanism on the Middle Triassic depo- sition is commonly witnessed in the Dinarides (ك̌ćavnićar et al., 1984; Kolar-Jurkovšek, 1990; Petek, 1998; Smirčić et al., 2016; Smirčić et al., 2018) as well as in the surrounding area of the western Tethyan realm (Brandner and Bechstädt, 1970; Obenholzner, 1991; Dimitrijević, 1997; Velledits, 2004, 2006; Kovács et al., 2011; Velledits et al., 2011). The limestone layer at the top of the massive grey limestones with shallow wa- 


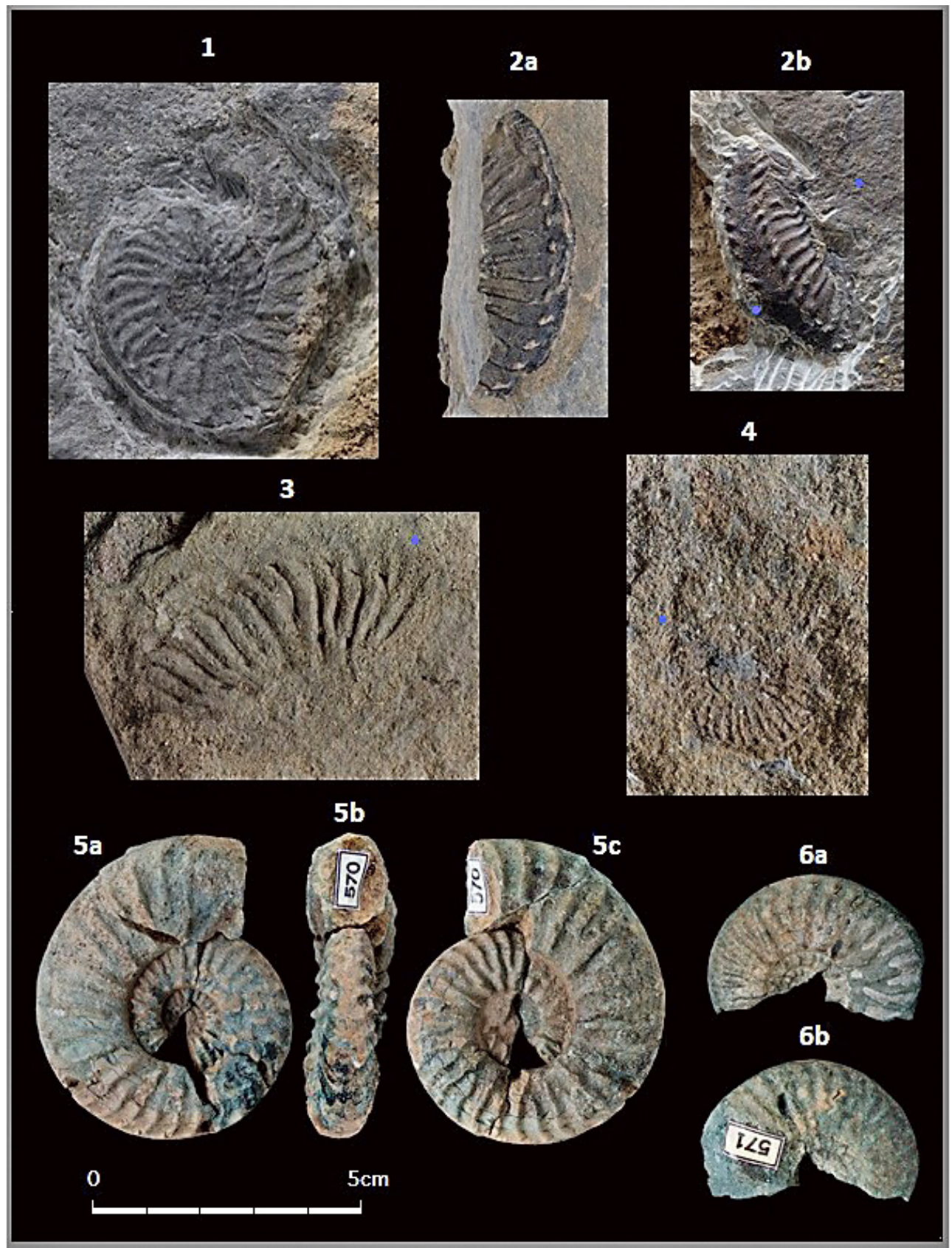

Figure 7. 1. Reitziites reitzi (BÖCKH, 1872) - INV 1027, Kunovac l., Reitzi Zone, lateral view, 2. Reitziites reitzi (BÖCKH, 1872) - INV 1029, Kunovac 1., Reitzi Zone, a: lateral view, b: ventrolateral view 3. and 4. Resembling Reitziites cf. reitzi (BÖCKH, 1872) (as suggested by A. Vörös) - INV 1027, Kunovac 1., Reitzi Zone, lateral view 5. Asseretoceras sp. (BALINI, 1992) - INV 570, Kunovac 1., upper part of the Paraceratites trinodosus Zone a: lateral view, b: ventral view, c: lateral view. 6. Asseretoceras sp. (BALINI, 1992) - INV 571, Kunovac 1., upper part of the Paraceratites trinodosus Zone (?), a and b: lateral views.

ter depositional characteristics contains hipidiomorphic to idiomorphic plagioclase crystaloclasts and volcanic lithoclasts (interval 2 - Figure 2). The shapes of the crystaloclasts suggest the vicinity of the primary eruption and possible air fall into a shallow marine depositional area. The volcanic activity was accompanied by tectonic movements causing the uplifting and subsiding of the blocks. The tectonic movements were probably very intensive, and the large scaled fault movements caused drastic changes in the depositional areas. Limestones deposited in the upper part of the interval of limestones interlayered with pyroclastics contain pelagic biota supported by lime mud, indicate slow and steady suspension settling in the pelagic conditions. Drowning of the shallow marine environments, previously dominated by limestone deposition, followed. Limestones in 
interval 3 (see Figure 2) are interlayered with crystaloclastic and vitriclastic tuffs, indicating eruptional episodes of the nearby volcanic systems (intervals 3 and 4 - Figure 2). The beginning of the Kunovac section, divided from the Mali Kunovac by cca $10 \mathrm{~m}$ covered interval (interval 5 - Figure 2), is marked by the lithoclastic limestones containing fragments of the shallow marine limestones. This indicates erosion of the material from the shallow marine environment and redeposition by gravity flows to the deeper marine areas (interval $6-$ Figure 2). The erosion of the limestones was related to the tectonic activity that persisted throughout the period of deposition. The pelagic sedimentation continued after this by the suspension settling of lime mud and the dominance of pelagic fossils. The pyroclastics on top of the recorded section (interval 7 - Figure 2) witness the new eruptional episode. This pyroclastic interval is composed of vitriclastic and crystaloclastic tuff layers, suggesting resedimentation by gravity flows or pyroclastic density currents (Di Capua and Gropelli, 2016) from the shallower areas where the pyroclastic material was primarily deposited.

\section{Discussion}

Similar depositional features as described for the investigated sections Mali Kunovac and Kunovac, have already been documented in different parts of the Dinarides, which represents a vast marine area with small horsts (highs with shallow water, platform-like deposition) and intraplatform depressions - grabens (with pelagic-type deposition) (e.g. Šćavničar et al., 1984; Belak, 2000; Smirčić et al., 2018). In the investigation of the Middle Triassic deposits of the Svilaja Mts. near Sinj (cca $150 \mathrm{~km}$ from sections investigated in this work), Śćavničar et al. (1984) recognized two basalt occurrences and associated tuff horizons. The authors stated that the first basalt effusion had already started in Anisian, while the second basalt and tuff horizon belong to the Ladinian. These two mentioned volcanic/tuff horizons suggest similar time intervals as in the investigated sections described in this study. The discovery of the Asseretoceras sp. indicates that the lower part of the section belongs to the topmost part of the Illyrian Paraceratites Trinodosus Zone. According to the Reitziites reitzi species, found in the first tuff interval/interlayer from the Mali Kunovac section, the age of this short interval is the late Illyrian (Reitziites reitzi Zone after Vörös, 2014; 2019). Consequently, the volcanism in the Dinarides began already in the Anisian, as concluded also in Smirčić et al. (2018). The second tuff interval, on top of the Kunovac section, certainly represents younger deposits. There is no biostratigraphic proof of its Ladinian age, so far.

Tectonic and volcanic activity in the Middle Triassic was related to the opening of the Tethyan Ocean and the disintegration of Pangea. Evidence of the volcanic activity can be traced in the whole area of western Tethys, with its peak and termination in the late Illyrian (Vörös, 2014; Smirčić et al., 2018). Tectonic activity caused the intensive differentiation of the sedimentary environments forming deep marine, shallow marine and continental sedimentary environments in a relatively short distance one from another. This differentiation of the marine areas probably caused the more intensive fluctuation of the nutritive rich sea water, thus causing blossoming of the marine organisms. This also affected ammonoids since many genera appear in the late Anisian Reitziites reitzi Zone (Hungarites, Parakellnerites, Aplococeras, Latemarites), which were ecologically related to platform or peri-platform areas (Vörös, 2014; 2019).

Grimani et al. (1975) and Sokač et al. (1976) indicate that the deposits in the area of Kunovac are Ladinian in age. This study, according to the new stratigraphic division of the Middle Triassic by Brack et al. (2005), proves differently. The index fossil Reitziites reitzi precisely indicates the Reitziites reitzi Zone (see Figure 4) (Brack and Rieber, 1993; Mietto et al., 2003; Brack et al., 2005; Balini et al., 2010) of the upper Illyrian and correlates well with the volcanic deposits in the other areas in the Dinarides (Smirčić et al., 2018).

\section{Conclusion}

The two recorded sections in southern Lika form a rather short but unique and significant depositional sequence. In the whole sequence, a severe and abrupt change of lithology occurs, from shallow marine limestones with abundant green algae interlayered with pyroclastics, to the pelagic limestones with thin-shell bivalves and radiolarians, accompanied with tuffs. These differences in the composition can indicate tectonic activity accompanied with volcanic eruptions at the time of the deposition. The rifting tectonic movements caused severe changes of depositional environments and an abrupt differentiation of lithological characteristics. Pyroclastic material, found in the rocks from both environments (shallow and deeper marine), indicates persistence of the volcanic activity, starting already in the Anisian (late Illyrian). Two main tuff horizons are supposed, one in the Mali Kunovac section, determined as late Illyrian in age, and the second at the top of the $\mathrm{Ku}$ novac section, representing younger strata. The lower part of the section is marked by the Asseretoceras sp., indicating the upper part of the Illyrian Paraceratites trinodosus Zone. The first tuff interval and the first finding of the Reitziites reitzi ammonoid species marks the upper Illyrian Reitziites reitzi Zone. The first record of the Reitziites reitzi in the Karst Dinarides directly constrains the beginning of the volcanic activity to the upper Illyrian. The occurrence of rich cephalopod fauna indicates that the deposition took place in an open marine environment with shallow marine areas existing nearby, as suggested by the presence of the shallow marine limestone lithoclasts in the pelagic environment. 


\section{Acknowledgments}

This research was partly financed by the financial support of the University of Zagreb. This research was a part of the MS thesis made by Nikolina Gaberšek, and supervised by Duje Smirčić and Uroš Barudžija. The authors are grateful to Attila Vörös and two anonymous reviewers for their useful suggestions and comments, which highly improved the manuscript. The authors also wish to thank Nives Borčić from the Croatian Natural History Museum in Zagreb for her help during field work and taking the photographs of the cephalopod fauna.

\section{References}

Balini, M. (1992): New genera of Anisian ammonoids from the Prezzo Limestone (Southern Alps). Atti Ticinensi di Scienze della Terra 35, 179-198.

Balini M., Lucas, S.G., Jenks, J.F. and Spielmann, J.A. (2010): Triassic ammonoid biostratigraphy: an overview. In: Lucas, S.G. (ed.): The Triassic Timescale. Geological Society of London, London, Special Publications 334, 221-262.

Belak, M. (2000): Postaja 2: Profil Sutina-Zelovo Sutinsko; Kristaloklastični i vitoroklastični tufovi (pietra verde) $\mathrm{s}$ proslojcima silicificiranih dolomita, vapnenaca, tufita i rožnjaka. [Stop 2: Sutina-Zelovo Sutinsko profile: Crystalloclastic and vitroclastic tuffs (pietra verde) interlayered with silicified dolomites, limestones, tuffites and cherts.] In: Jelaska, V., Benček, Đ., Matičec, D., Belak, M., Gušić, I.: Geološka povijest i strukturna evolucija Vanjskih Dinarida. [Geological history and the structural evolution of the External Dinarides] Fieldtrip guidebook (Vlahović, I. and Biondić, R., (eds.)). 2. Croatian Geological Congress, Cavtat-Dubrovnik, 6-9, IGI, Zagreb. (in Croatian)

Böckh, J. (1872): A Bakony déli részének földtani viszonyai. I. [The geological features of the southern part of the Bakony. I.] - A Magyar Királyi Földtani Intézet Évkönyve 2 (2), 31-166. (in Hungarian)

Brack, R. and Rieber, H. (1993): Towards a better definition of the Anisian/Ladinian boundary: New biostratigraphic data and correlations of boundary sections from the Southern Alps. Eclogae geologicae Helvetiae 86, 415-527.

Brack, P., Rieber, H., Nicora, A. and Mundil, R. (2005): The Global Stratotype Section and Point (GSSP) of the Ladinian stage (Middle Triassic) at Bagolino (Southern Alps, Northern Italy) and its implications for the Triassic time scale. Episodes, 4, 233-244.

Brandner, R. and Bechstädt, T. (1970): Carbonatic and clastic sediments correlated to synsedimentary tectonics. Verhandlung der Geologischen Bundesanstalt, 4, 545-548.

Di Capua, A. and Gropelli, G. (2016): Application of actualistic models to unravel primary volcanic control on sedimentation (Taveyanne Sandstones, Oligocene Northalpine Foreland Basin). Sedimentary Geology, 336, 147-160.

Dimitrijević, M.D. (1997): Geology of Yugoslavia. In: Karamata, S. and Krstić, B. (eds.), Geological institute GEMINI, Belgrade, $187 \mathrm{p}$.

Grimani, I., Šikić, K. and Šimunić, An. (1972): Basic Geological Map of SFR Yugoslavia, 1:100 000, Knin sheet.
Institut za geološka istraživanja Zagreb, Savezni geološki zavod Beograd. (in Croatian)

Grimani, I., Šikić, K. and Šimunić, An. (1975): Basic Geological Map of SFR Yugoslavia, 1:100 000, Geology of Knin sheet, Institut za geološka istraživanja Zagreb, Savezni geološki zavod Beograd, 61 p. (in Croatian)

Ivanović, A., Sakač, K., Marković, S. and Sokač, B. (1973): Basic Geological Map of SFR Yugoslavia, 1:100 000, Obrovac sheet. Institut za geološka istraživanja Zagreb, Savezni geološki zavod Beograd. (in Croatian)

Koch, F. (1911): Prilog geologiji Velebita i hrvatskog krša. Izvještaj montangeološke sekcije za godinu 1911. [Contribution to the geology of the Velebit Mt. and Croatian karst. Montangeological Section Report for year 1911.] Vijesti geološkog povjerenstva, II, 17 p. (in Croatian)

Kolar-Jurkovšek, T. (1990): Mikrofavna srednjega in zgornjega triasa Slovenije in njen biostratigrafski pomen. [Microfauna of the Middle and Upper Triassic deposits in Slovenia and their biostratigraphic significance.] Geologija, 33, 21-170. (in Slovenian)

Kovács, S., Sudar, M., Grădinaru, E., Gawlick, H.-J., Karamata, S., Haas, J., Péró, C., Gaetani, M., Mello, J., Polák, M., Aljinović, D., Ogorelec, B., Kolar-Jurkovšek, T., Jurkovšek, B. and Buser, S. (2011): Triassic evolution of the tectonostratigraphic units of the Circum-Pannonian Region. Jahrbuch der Geologischen Bundesanstalt, 151, 199-280.

Mietto, P., Gianolla, P., Manfrin, S. and Preto, N. (2003): Refined ammonoid biochronostratigraphy of the Bagolino section (Lombardian Alps, Italy), GSSP candidate for the base of the Ladinian Stage. Rivista Italiana di Paleontologia e Stratigrafia 109, 449-462.

Mojsisovics, E. (1882): Die Cephalopoden der mediterranen Triasprovinz. Abhandlungen der kaiserlich-königlichen geologischen Reichsanstalt 10, 1-322. (in German)

Obenholzner, J.H. (1991): Triassic volcanogenic sediments from the Southern Alps (Italy, Austria, Yugoslavia) - a contribution to the „Pietra verde“ problem. Sedimentary Geology, 74, 147-171.

Petek, T. (1998): Skitske in anizijske plasti v kamenolomu Hrastenicah in pomembne najdbe zgornjeanizijskih fosilov. [Scythian and Anisian beds in Hrastenica Quarry and the significant findings of Upper Anisian fossils.] Geologija, 40, 119-151. (in Slovenian)

Salopek, M. (1914): O naslagama s okaminama od Kunovac vrela u Lici. [On the fossiliferous beds from Kunovac Vrelo in Lika.] Prirodoslovna istraživanja, Jugoslavenska akademija znanosti i umjetnosti (JAZU). 4, 1-23. (in Croatian)

Smirčić, D., Lugović, B., Aljinović, D., Hrvatović, H., KolarJurkovšek, T., Jurkovšek, B. and Gajšak, F. (2016): Middle Triassic autoclastic deposits from Southwestern Bosnia and Herzegovina. Rudarsko-geološko-naftni zbornik, 2, 1-12. https://doi.org/10.17794/rgn.2016.2.1

Smirčić, D., Kolar-Jurkovšek, T., Aljinović, D., Barudžija, U., Jurkovšek, B. and Hrvatović, H., (2018): Stratigraphic definition and correlation of Middle Triassic volcaniclastic facies in the External Dinarides: Croatia and Bosnia and Herzegovina. Journal of Earth Science, 29, 864-878. https://doi.org/10.1007/s12583-018-0789-1 
Sokač, B., Šušnjar, M., Bukovac, J. and Bahun, S. (1976): Basic Geological Map of SFR Yugoslavia, 1:100 000, Geology of Udbina sheet. Institut za geološka istraživanja Zagreb, Savezni geološki zavod Beograd, 58 p. (in Croatian)

Šćavničar, B., Šćavničar, S. and Šušnjara, A. (1984): The volcanic-sedimentary Middle Triassic in the Suvaja brook area (Mt. Svilaja, Outer Dinarides). Acta Geologica, 14, $35-82$.

Šušnjar, M., Sokač, B., Bahun., S., Bukovac, J., Nikler, L. and Ivanović, A. (1973): Basic Geological Map of SFR Yugoslavia, 1:100 000, Udbina sheet. Institut za geološka istraživanja Zagreb, Savezni geološki zavod Beograd. (in Croatian)

Šušnjar, M., Bukovac, J., Savić, D., Sikirica, V. and Marinčić, S. (1978): Basic Geological Map of SFR Yugoslavia, 1:100000, Drvar sheet. Institut za geološka istraživanja Zagreb, Savezni geološki zavod Beograd. (in Croatian)

Velledits, F. (2004): Anisian terrestrial sediments in the Bükk Mountains (NE Hungary) and their role in the Triassic rift- ing of the Vardar-Meliata branch of Neo-Tethys Ocean. Rivista Italiana di Paleontologia e Stratigrafia, 110, 659-679.

Velledits, F. (2006): Evolution of Bükk Mountains (NE Hungary) during the Middle-Late Triassic asymmetric rifting of the Vardar-Meliata branch of the Neotethys Ocean. International Journal of Earth Sciences, 95, 395-412.

Velledits F., Péró Cs., Blau J., Senowbari-Daryan B., Kovács S., Piros O., Pocsai T., Szügyi-Simon H., Dumitrică P. and Pálfy J. (2011): The oldest Triassic platform margin reef from the Alpine-Carpathian Triassic, Aggtelek, NE Hungary. Rivista Italiana di Paleontologia e Stratigrafia: 1772, 221-268.

Vörös, A. (2014): Ammonoid diversification in the Middle Triassic: Examples from the Tethys (Eastern Lombardy, Balaton Highland) and the Pacific (Nevada). Central European Geology. Acta Geologica Hungarica, 57, 319-343.

Vörös, A. (2019): The Upper Anisian ammonoids of the Balaton Highland (Middle Triassic, Hungary). Acta Geologica Hungarica, 60, 1-241.

\section{SAŽETAK}

\section{Prvi nalaz Reitziites reitzi markera gornjoiliričke amonitne podzone u krškim Dinaridima}

Srednjotrijaske naslage u krškim Dinaridima (okolica Gračaca u južnoj Lici) istraživane su s ciljem njihove petrološke i sedimentološke odredbe te odredbe njihove biostratigrafske pripadnosti. Unutar dvaju snimljenih kontinuiranih sljedova koji se sastoje od izmjene karbonatnih sedimentnih stijena i piroklastita (Mali Kunovac i Kunovac), a koji odražavaju varijabilne sedimentacijsko-magmatske okoliše njihova postanka, prikupljena je relativno malobrojna, ali vrijedna kolekcija cefalopoda srednjoiliričke i gornjoiliričke starosti. Najvažniji su nalazi amonitne vrste Asseretoceras sp. koja upućuje na gornji dio iliričke Paraceratites trinodosus zone te vrste Reitziites reitzi koja označava gornjoiliričku Reitziites zonu. Pronalazak vrste Reitziites reitzi do sada nije bio zabilježen na području krških Dinarida.

\section{Ključne riječi:}

krški Dinaridi, Hrvatska, srednji trijas, biostratigrafija, amoniti

\section{Authors contribution}

Duje Smirčić orcid.org/oooo-0oo2-636o-8203 (PhD, senior researcher, sedimentology/volcaniclastic rocks) along with Nikolina Gaberšek (MS), Dunja Aljinović orcid.org/oooo-ooo2-4698-1727 (PhD, Full Professor, sedimentology/carbonates) and Uroš Barudžija orcid.org/oooo-ooo2-1617-9362 (PhD, Assistant Professor, sedimentology/diagenesis) conducted fieldwork, micropetrographically analysed the thin sections, determined the lithological characteristics of the rocks and proposed sedimentary processes and a model for the investigated deposits. Dražen Japundžić (MSc, senior curator, palaeontology) conducted field work and made paleontological and biostratigraphic determinations of the ammonoid specimens. Nediljka Prlj-Šimić (MSc, senior curator, cephalopod palaeontology), Katarina Krizmanić (MSc, senior curator, palaeontology) and Ivor Pavić (MS) conducted field work investigations. 